\title{
Speaking is a Challenging Skill in Language Learning
}

\author{
Saida Verdiyeva ${ }^{1}$, Farida Huseynova ${ }^{2}$ \\ ${ }^{1}$ Department of Foreign Languages-2, Azerbaijan State Oil and Industry University \\ ${ }^{2}$ Department of Foreign Languages-1, Azerbaijan State Oil and Industry University
}

\begin{abstract}
The aim of the research is to develop speaking skills and improve the efficiency of teaching English as a foreign language in our country. To be successful in achieving the aim, it is necessary to increase students' involvement and encouragement in the speaking process. With this purpose, it is inevitable to find out who our students are, their needs, and what approaches to use. Having answered all these questions, it is possible to engage them in the process of learning language with enthusiasm and increase English speaking skills competence by creating self-confidence in them.
\end{abstract}

Keywords- English, communicate, learning, research, speaking, student.

\section{INTRODUCTION}

As the effective teaching is based on communication, the goal of English teaching is exactly the same, namely to develop the ability of students to communicate with people in a new language in real world situations (Brown, 1987; Ommagio, 1986; Oxford, 1990; Widdowson, 1978).

There are many analysis and discussions on teaching speaking a foreign language.
The aim of this research is to determine reasons how to make students speak in the best way and improve their communicative skills in the classrooms.

The problem is that majority of students are aware of importance of speaking English language, but cannot afford it for various reasons.

This research on teaching English has been carried out to see why the students, who have been studying English for years, yet have problems in mastering communicative skills and what factors impact on the learners. Considering all the evidence in our research, we tried to find out what happens in our classrooms and how to encourage our students relevantly to learning English.

\section{METHODS OF ANALYSES}

In order to achieve the main goal of learning foreign languages i.e. to communicate in this language, it is necessary to find out the reasons which impede the process of developing speaking skills.

With this purpose a questionnaire for students has been developed and the problems in mastering speaking skills have been revealed. Fifty students with different speaking abilities from different faculties took part in this survey.

Table.1

1.What type of skill in learning English is the most important?

\begin{tabular}{|l|l|l|l|l|}
\hline Reading & Writing & Speaking & Listening & None \\
\hline 13 & 6 & 23 & 8 & 0 \\
\hline
\end{tabular}

2.When I speak English I am

\begin{tabular}{|l|l|l|l|l|}
\hline Confident & Embarrassed & Shy & Nervous & If other, specify \\
\hline 18 & 14 & 5 & 11 & $\begin{array}{l}2 \text { students Depends } \\
\text { on situation }\end{array}$ \\
\hline
\end{tabular}

3. While speaking English I feel embarrassed, nervous, shy because

\begin{tabular}{|l|l|l|l|l|}
\hline $\begin{array}{l}\text { It is difficult for me } \\
\text { to speak English }\end{array}$ & $\begin{array}{l}\text { My vocabulary is } \\
\text { not very well }\end{array}$ & $\begin{array}{l}\text { I am afraid to be } \\
\text { laughed at }\end{array}$ & $\begin{array}{l}\text { My pronunciation is } \\
\text { bad }\end{array}$ & \begin{tabular}{l} 
If other, specify \\
\hline 9
\end{tabular} \\
\hline 16 & 4 & 3 & $\begin{array}{l}18 \text { students Neither } \\
\text { nervous nor embarrassed }\end{array}$ \\
\hline
\end{tabular}

4.How much do you work on improving your English?

\begin{tabular}{|l|l|l|l|l|}
\hline One hour a week or less & Two hours a week & Three hours a week & Four hours a week & More than four hours \\
\hline 10 & 11 & 12 & 7 & 10 \\
\hline
\end{tabular}


5.How do you improve your speaking abilities?

\begin{tabular}{|l|l|l|l|l|}
\hline By watching TV & $\begin{array}{l}\text { By listening to } \\
\text { songs }\end{array}$ & By reading books & With teacher's help & If other, specify \\
\hline 12 & 8 & 10 & 16 & $\begin{array}{l}4 \text { students } \\
\text { Use all }\end{array}$ \\
\hline
\end{tabular}

6. How do you find classroom environment?

\begin{tabular}{|l|l|l|l|l|}
\hline Hostile & Unfriendly & Friendly & Interactive & If other, specify \\
\hline 0 & 10 & 28 & 12 & \\
\hline
\end{tabular}

7. The materials used in the classroom are

\begin{tabular}{|l|l|l|l|l|}
\hline Boring & Difficult & Enjoyable & Effective & If other, specify \\
\hline 13 & 12 & 9 & 13 & $\begin{array}{l}3 \text { students } \\
\text { informative }\end{array}$ \\
\hline
\end{tabular}

8.How often do you speak English?

\begin{tabular}{|l|l|l|l|l|}
\hline Always & Often & Sometimes & Seldom & Never \\
\hline 9 & 9 & 9 & 20 & 3 \\
\hline
\end{tabular}

9. I want to speak English

\begin{tabular}{|l|l|l|l|l|}
\hline To use it abroad & $\begin{array}{l}\text { To use it in my } \\
\text { future career }\end{array}$ & For myself & $\begin{array}{l}\text { To read books or } \\
\text { watch films in } \\
\text { English }\end{array}$ & If other, specify \\
\hline 8 & 20 & 8 & 4 & $\begin{array}{l}10 \text { students } \\
\text { everywhere }\end{array}$ \\
\hline
\end{tabular}

10. When do you feel confidence in speaking?

\begin{tabular}{|l|l|l|l|l|}
\hline Working in pairs & Working in a group & $\begin{array}{l}\text { When I work by } \\
\text { myself (in a } \\
\text { monologue speech) }\end{array}$ & $\begin{array}{l}\text { When I speak with a } \\
\text { teacher }\end{array}$ & If other, specify \\
\hline 8 & 12 & 12 & 14 & 4 students never \\
\hline
\end{tabular}

The survey shows that majority of students give priority to communicative abilities. And if they fail or cannot improve communicative skills, the interest to learning language falls. To clarify the reasons of possible failure, we decided to ask the next question, i.e. what they felt while speaking English. According to the results of the questionnaire, more than fifty percent of students felt embarrassed, and nervous, and shy, and two students had different feelings depending on situation. Those students who felt embarrassed, nervous and shy were suggested to answer to one more question: what problems caused them to have those feelings; and it appeared that most of them had difficulties with vocabulary and sentence construction in speaking. For many students, the fear of making mistakes while speaking holds them back and inhibits their communication. Those students who felt confident while speaking didn't answer this question. By means of the above mentioned questions we determined how much time the students spent on learning the language, how they developed language skills, and if the materials and class environment suited them; how often they used English and why they learnt English. The questions and answers helped us to know our students better, know their problems and needs.

It is necessary to take into account, that our students are multilingual: (they speak fluently Azerbaijani, Russian, Turkish, and besides, people of ethnic groups, can speak in their own native language too). English language for them is the third or fourth language. The students are mature in learning languages, and they are aware of the importance of English language, too; they want to learn English language as the other languages. Then, what is the main problem?

According to Stephen Krashen,there are two independent systems of second language performance: "the acquired system" and "the learned system". The "acquired system" or "acquisition" is the product of a subconscious process very similar to the process that children undergo when they acquire their first language. 
In view of all that has been mentioned so far, it is supposed that English language must be taught in a distinguished - "acquired" way in our classrooms.Bothcultural aspects and some specific features should be taken into consideration in the process. In this case, differentcontent-basedspeaking activities should be practicedstep by step every day to enable the students to speak English, and communicate in it.The students must be ready to find out relevant spoken words for communication- select appropriate words and sentences according to the proper situation, audience, and subject matter.

According to the objectives of research and students' needs, we decided to pay more attention to speaking skills because "Speaking is an interactive process of constructing meaning that involves producing and receiving and processing information “(Brown, 1994; Burns \& Joyce, 1997).

\section{DISCUSSION}

Here are many good reasons to be skeptical when the students do not speak English or deny saying anything in it; as the learning of a language is a complex and multistaged process.

Since the purpose of learning English is mainly an attempt to communicate with individuals, effective language teaching is based on communication and aims at developing students' ability to communicate with people in a new language in real world situations (Brown, 1987; Ommagio, 1986; Oxford, 1990; Widdowson, 1978).

The learning of a language means 'to speak the language',however, the students feel hesitant as there is fear of speaking English. The students face difficulties in using even familiar words and phrases in speech.Much attentionshould be paidto the students' personal traits and cultural differences.

Our students wish to master English as they did it in learning previous languages, in natural way. But in the case of acquiring English language, it becomes difficult, because students cannot learn the languageonly by using it in the classroom, as they do not hear and communicate with native speakers. They face difficulties in putting ideas into words.Thisprocess is interrupted before the learning process really begins, and they are demotivated to learn English.

Learning speaking means "leading to automatization of language production, emerged as an important aspect of formulaic language processing”(G. Dillon ,2015).

Our analyses proved that it would be better to provide automatization of language process not only by mechanical skills, but also by understanding of language content.
Other significant aspects were discovered inacquisition of the language:

- insufficient input

- lack of practice

- $\quad$ shortage of variety of teaching aids

\section{RESULTS}

The needs of students made use the new strategies in teaching process. Here are some activities which can be suggested to students to develop speaking skills:

1. According students' needs and interests the teacher chooses appropriate topic for a small talk. Students can discuss the topic, either in the groups or individually, share ideas about an event, find solutions in their group discussions.

2. Show the students a picture of businessmen speaking in the office. Ask the students to brainstorm what the people in the picture might be discussing.

3. Show video films. The students watch the half of the film. Ask the students to work in groups and make predictions. Similar activity can be provided with reading and listening tasks. Students read or listen the half of the story and then predict the end of the story.

4. Dialogueson real-life communications can beconducted with the purpose of information exchange; such activities as information-gathering interviews, role plays, or debates make students be engaged in improvised situations and use phrases they know.

5. Monologues such as short speeches, oral reports, presentations or oral summaries help students to organize their speech, and reproduce it.

Besides, other communicative activities can be practiced: conversation card activities, problem solving assignments, and many others.

All these activities should be provided with the necessary vocabulary beforehand.

To encourage the students to become self-directed and responsible decision makers, participate actively on their own learning, TBL and PBL methods of teaching were widely used at the lessons.

Using these teaching methods makes students be actively engaged in group, pair, team, individual work. These methods require classroom dynamics which involve the students in a socializing process. By providing maximum opportunity for students to speak more,theirshyness can be decreased,andthey become encouraged to learn by doing. Pair and team workcan be very challenging for students, and they can overcomeall the difficult tasks together. As speaking and self-confidence are interrelated, students interact with each other using small talks or making small reports; practice the language by different kinds of activities, anddevelop speaking skills step by step by gaining confidence. Maximizing the limited resources 
and classroom-based approach, and engagement in English language speaking process fosters fluency of speech.
The following table showswidely used activities which can help to develop communicative skills within ten weeks.

Table. 2

\begin{tabular}{|c|c|c|c|c|c|c|c|c|c|c|}
\hline 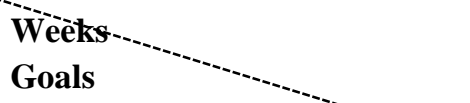 & 1 & 2 & 3 & 4 & 5 & 6 & 7 & 8 & 9 & 10 \\
\hline Create a favourable atmosphere & + & + & + & + & + & + & + & + & + & + \\
\hline Provide contextualized learning & + & + & + & + & + & + & + & + & + & + \\
\hline $\begin{array}{l}\text { Widely use TBL and PBL } \\
\text { methods }\end{array}$ & & & + & + & + & + & + & + & + & + \\
\hline $\begin{array}{l}\text { Provide independent work and } \\
\text { give much autonomy }\end{array}$ & + & + & + & + & + & + & + & + & + & + \\
\hline Play games using language & & + & & + & & + & + & + & & + \\
\hline $\begin{array}{l}\text { Use authentic materials (movies, } \\
\text { cartoons, magazines etc.) }\end{array}$ & & & & + & & + & & & + & \\
\hline $\begin{array}{l}\text { Engage students in making } \\
\text { posters, presentations etc. }\end{array}$ & & & & & + & + & + & & & + \\
\hline
\end{tabular}

Practicing above mentioned activities gave us good results in acquiring speaking skills.

Competence in speaking acquired easily, rapidly and naturally with a lot of fun, raised learner's motivation and made the English language classroom a place of entertainment, where the students could carry out conversations. Their language knowledge and speech rate increased; in addition, the number of hesitations decreased by daily actions and practices. They could succeed in carrying out conversation. Therefore, speaking was acquired by meaningful interaction in the target language - natural communication, where speakers were concentrated not on the parts of the language, but in the communicative activities.

\section{CONCLUSION}

In brief, according to our objectives, giving priority to speaking skills by variety of practice with high frequency,providing a learner -centered approach, practicing mechanicalskills the students could improve their communicative abilities.

As a result, we could get the following outcomes:

- The increase of students' interest and ability of speaking;

- The increase of students' cognitive skills;

- Development of competence;
- Avoidance of persistence lack and expectations of failure;

- Ability to fulfill challenging speaking tasks;

- Increase students' self-confidence in speaking;

- Ability to work autonomously;

- Ability to cooperate with each other.

The students become better speakers by a lot of speaking and by a lot of listening. It is advisable to focus on teaching by the right activities in the right way and utilize all the resources available to them.

\section{REFERENCES}

[1] Brown,H.D.(1987). Principles of language learning and teaching. Englewood Cliffs,N.J.: Prentice-Hall

[2] Brown, H.D. (1994). Teaching by principles: an interactive approach to language pedagogy. Englewood Cliffs, NJ: Prentice Hall Regents.

[3] Burns, A., \& Joyce, H. (1997). Focus on speaking. Sydney: National Center for English Language Teaching and Research.

[4] Dillon,G.(2015). A Formula for Fluency? University of Dublin, Trinity College Centre for Language and Communication Studies.

[5] Krashen, Stephen D. (1988). Second Language Acquisition and Second Language Learning. Prentice-Hall International. 
[6] Ommagio, A. (1986).Teaching language in context. Boston: Heinle and Heinle.

[7] Widdowson,H.G. (1978). Teaching Language as communication. London:Oxford University Press. 